Jurnal Pilar Teknologi, Volume 3 Nomor 2 Edisi September 2018

ISSN Print : 2502-7042 ISSN Online : 2580-3557

http://pilar.unmermadiun.ac.id

\title{
Sistem Pendukung Keputusan Pemilihan Atlet Panahan Menggunakan Metode Analitycal Hierarchy Process Berbasis Web
}

\author{
Eka Bayu Bimantara ${ }^{1}$, Arief Budiman ${ }^{2}$, Pradityo Utomo ${ }^{3}$

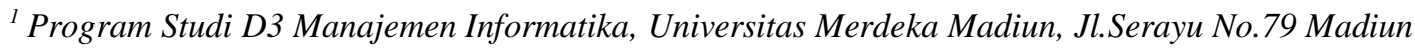 \\ E-mail: ebayu9110@gmail.com \\ ${ }^{2}$ Program Studi D3 Manajemen Informatika, Universitas Merdeka Madiun, Jl.Serayu No.79 Madiun \\ E-mail: arief.b.mn@gmail.com \\ ${ }^{3}$ Program Studi D3 Manajemen Informatika, Universitas Merdeka Madiun, Jl.Serayu No.79 Madiun \\ E-mail: pradityo@unmer-madiun.ac.id
}

\begin{abstract}
Decision Support System is a system was used to help getting making decisions on a problem, such as selecting students in the archery sports that will be face to a championship event such as SEA GAMES (South East Games). In Decision Support System there are many methods that can be used, one of them is Analitycal Hierarchy Process method. Analitycal Hierarchy Process method is one of the more efficient decision-making methods because the data is very detailed, all the criteria and alternatives will be compared one by one. The calculation used to solve a problem uses multiplication to relate the preference value, where the value for each criteria and alternative must be searched for eigen / priority vector first, after it is proved consistency using RI table (ratio index), if the result of verification is less than $10 \%(0.1)$ then it is consistent and the calculation can be continued, but if the verification result is more than 10\% (0.1) then the calculation is considered inconsistent and needs to be repeated from the beginning. This support system uses a web base, where the data entered will be saved into the MySQL database. The test results of the Student Selection Selection Decision Support System Using Analitycal Hierarchy Process Method Based Web get results as expected on the Black Box. So it can be concluded an accurate percentage of system success of $100 \%$.
\end{abstract}

Keywords : Decision Support System, Black Box, Analitycal Hierarchy Process, The Selection Of Athlete.

\section{PENDAHULUAN}

Teknologi informasi saat ini merupakan salah satu teknologi yang sedang berkembang sangat pesat. Semakin lama dapat dirasakan bahwa pengelolaan data dengan cara manual semakin banyak menunjukan kelemahan. Sementara itu semakin ke depan semakin banyak persaingan dan datadata yang dikelola. Menggunakan tenaga manusia untuk mengelola data yang banyak akan mengurangi efektivitas dan keakuratan, karena manusia mempunyai keterbatasan dalam pengerjaannya. Di samping itu, keterlambatan dalam menerima informasi dapat menyebabkan tertundanya pencapaian tujuan dan akhirnya akan menggangu perkembangan perusahaan.

Adapun yang menjadi tujuan penulisan dalam penyusunan laporan ini adalah untuk membangun sebuah sistem pendukung keputusan pemilihan atlet panahan menggunakan metode Analitycal Hierarchy Process berbasis web di Persatuan Panahan Indonesia (PERPANI) cabang Madiun.

Beberapa penelitian telah dilakukan oleh Rudy Setiawan pada tahun 2011. Pada penelitian tersebut telah dibuat aplikasi system pendukung keputusan untuk mmenentukan kelayakan polisi dalam memegang senjata api menggunakan scoring system. Penelitian tersebut sudah melewati pengujian melalui black box dan berhasil berjalan dengan (Setiawan, 2011). Penelitian lain juga telah dilakukan, salah satunya dilakukan oleh Aji Setyawan dan Sutariyani pada tahun 2013 menghasilkan aplikasi sitem pendukung keputusan seleksi calon atlit bulutangkis berbakat pada studi kasus di PB. Djarum Kudus. Aplikasi tersebut dikerjakan dengan menggunakan metode Analitycal Hierarchy Process dan menggunakan bahasa pemrograman Hypertext Prepocessor (PHP). Aplikasi telah diuji dengan menggunakan white box dan berhasil berjalan dengan baik (Setyawan, Sutariyani, 
2013). Di tahun 2016 penelitian sejenis juga dilakukan oleh Rizky Bangkit P L, Rekyan Regasari M P dan Wayan Firdaus Mahmudy. Penelitian tersebut dilakukan pada studi kasus universitas sebelas maret Surakarta dan membuahkan hasil system pendukung keputusan pemilihan atlet yang layak masuk tim pencak silat. Penelitian tersebut menggunakan metode Simple Additive Weighting (SAW) dan dibangun dengan menggunakan bahasa pemrograman PHP (Bangkit dkk, 2016).Pada tahun 2016 penelitian terkait juga dilakukan oleh Afif Setyo Nugroho. Penelitan tersebut menghasilkan Sistem Pendukung Keputusan Seleksi Atlet PON Hockey Kontingen Jawa Tengah Menggunakan Metode AHP dan Promethee serta telah diimplementasikan pada framework sehingga aplikasi dapat digunakan pada perpustakaan stimik Asia Malang dengan baik (Nugroho, 2016). Penelitian juga dilakukan oleh Wirhan Fahrozi, dan menghasilkan Penerapan Metode AHP dalam Menentukan Ras Ayam Serama. Telah dilakukan pengujian dengan software expert choice dan dapat berjalan dengan baik dan akurat (Fahrozi, 2016). Pada saat yang sama penelitian juga dilakukan oleh Dino Rimantho, Marrie Rachel, Bambang Cahyadi dan Yan Kurniawan. Penelitian tersebut membuahkan hasil Aplikasi AHP Pada Pemilihan Metode Analisis Zat Organik Dalam Air serta telah mengalami pengujian dengan Total Organic Carbon, akurasi yang didapat mencapai 90\% (Rimantho dkk, 2016). Di tahun 2017 penelitian yang sama dilakukan oleh Armiyana dan Reski May Candra, penelitian tersebut menghasilkan Sistem Pendukung Keputusan Pemilihan Sekolah Anak Dengan Metode Analitycal Hierarchy Process dan Metode Perbandingan Eksponsional. Aplikasi tersebut telah diuji dengan menggunakan blackbox dan berhasil memenuhi harapan (Armiyana, Reski, 2017).

\section{METODE PENELITIAN}

Metodologi yang digunakan dalam penulisan penelitian ini adalah sebagai berikut:

1. Identifikasi Masalah

Merupakan tahap suatu proses dan hasil pengenalan masalah atau inventarisasi masalah, dengan kata lain identifikasi masalah adalah salah satu proses yang bisa dikatakan langkah paling penting diantara langkah langkah proses yang lain.

2. Studi Literatur

Merupakan tahap pembelajaran tentang masalah yang dihadapi dan solusi yang akan digunakan dalam penyelesaian masalah.

3. Pengumpulan Data

Merupakan tahap pengumpulan data dengan cara observasi, mengumpulkan literatur, jurnal, paper dan bacaan bacaan yang ada kaitannya dengan judul penelitian.

4. Analisis Sistem

Merupakan tahap menganalisis hal-hal yang diperlukan dalam pelaksanaan proyek pembuatan sistem.

5. Perancangan Sistem Merupakan tahap merancang dan membangun sistem berdasarkan data-data yang telah dikumpulkan.

6. Implementasi Sistem Merupakan tahap penerapan sistem yang dibuat kedalam bahasa pemrograman PHP.

7. Pengujian Sistem
Merupakan tahap uji coba terhadap sistem yang sudah jadi, apakah sudah berjalan dengan benar atau masih ada perbaikan.

8. Evaluasi

Merupakan tahap mengambil kesimpulan apakah sistem tersebut sudah layak untuk digunakan atau tidak.

\section{HASIL DAN PEMBAHASAN}

Dalam perancangan sistem peneliti menggunakan ERD. Entity Relationship Diagram (ERD) merupakan teknik yang digunakan untuk memodelkan kebutuhan data dari suatu organisasi, biasanya oleh sistem analis dalam tahap analisis persyaratan proyek pengembangansistem. Sementara itu seolah-olah teknik diagram atau alat peraga memberikan dasar untuk desain databse rasional yang mendasari sistem informasi yang dikembangkan. Adapun ERD dari Sistem dapat ditampilkan pada Gambar 1.

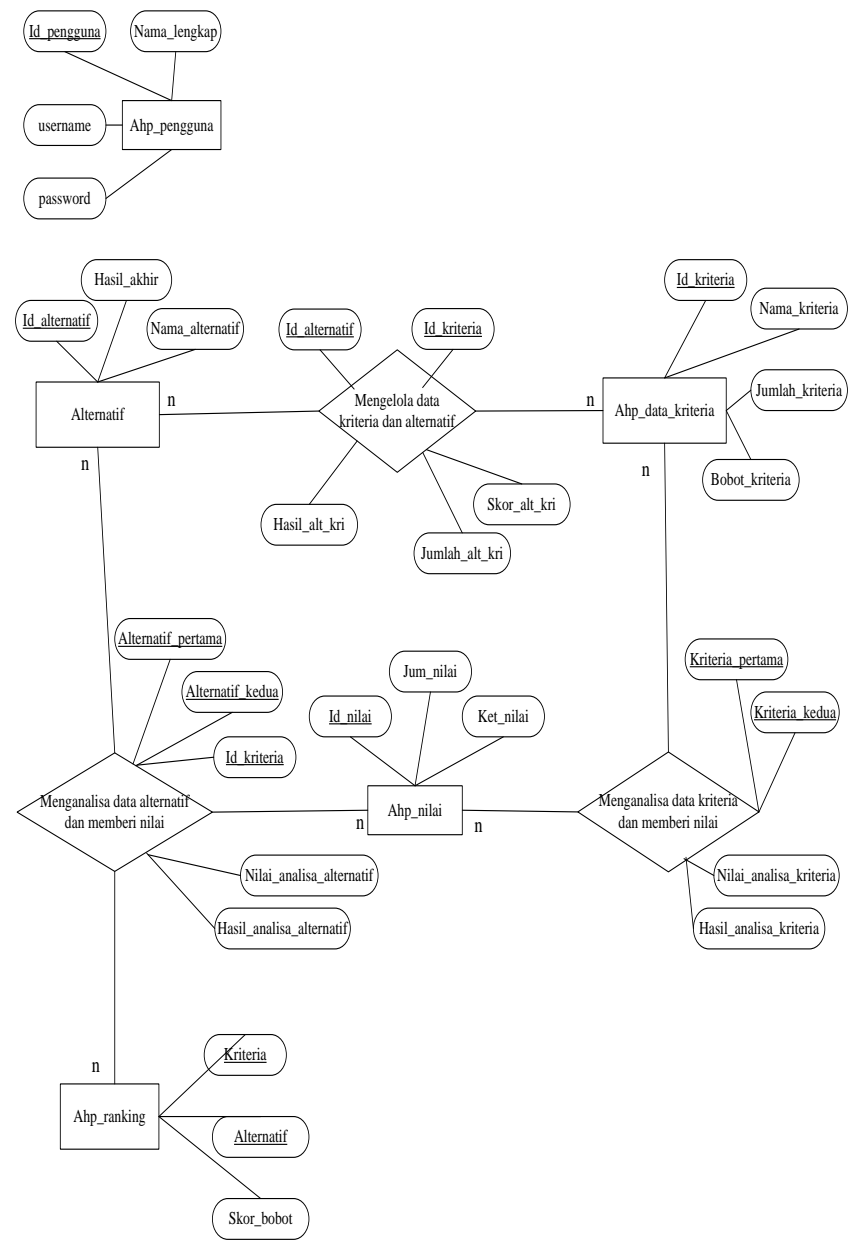

Gambar 1. ERD

Pada Gambar 1 telah disajikan ERD dari Sistem, berikut merupakan Entity Relationship Diagram dari program yang penulis rancang. Database dari Sistem Pendukung Keputusan dengan metode Analitycal Hierarchy Process ini mempunyai 8 tabel, yaitu tabel ahp_nilai, tabel ahp_pengguna, tabel ahp_data_kriteria, tabel ahp_data_alternatif, tabel ahp_jumlah_analisa_kriteria, tabel ahp_analisa_kriteria, tabel ahp_analisa_alternatif dan tabel ahp_ranking. Tabel ahp_nilai mempunyai 3 terminator yaitu id_nilai, jumlah_nilai dan 
keterangan_nilai. Tabel ahp_pengguna mempunyai 4 terminator yaitu id_pengguna, nama_lengkap, username dan password. Tabel ahp_data_kriteria mempunyai 4 terminator yaitu id_kriteria, nama_kriteria, jumlah_kriteria dan bobot_kriteria. Tabel ahp_data_alternatif mempunyai 3 terminator yaitu id_alternatif, nama_alternatif dan hasil_akhir. Tabel ahp_jumlah_analisa_kriteria mempunyai 5 terminator yaitu id_alternatif, id_kriteria, jumlah_alternatif_kriteria, skor_alternatif_kriteria dan hasil_alternatif_kriteria. Tabel ahp_analisa_kriteria mempunyai 4 terminator yaitu kriteria_pertama, nilai_analisa_kriteria, hasil_analisa_kriteria dan kriteria_kedua. Tabel ahp_analisa_alternatif mempunyai 5 terminator yaitu alternatif_pertama, nilai_analisa_alternatif, hasil_analisa_alternatif, alternatif_kedua dan id_kriteria. Tabel ahp_ranking mempunyai 3 terminator yaitu kriteria, skor_bobot dan alternatif.

Sementara itu prancangan pada database dapat diumpamakan sebagai sebuah tempat penyimpanan data yang terstruktur agar dapat diakses dengan cepat dan mudah. Dalam perancangan sistem informasi penjualan ini dibuat 8 tabel dalam database. Tabel - tabel tersebut adalah tabel pengguna, tabel nilai, tabel kriteria, tabel alternatif, tabel analisa kriteria, tabel analisa alternatif, tabel jumlah analisa kriteria, dan tabel ranking. Pembuatan database dan tabel-tabel menggunakan MySQL PhpMyAdmin.

Konteks Unified Modelling Language (UML) Sistem Pendukung Keputusan Pemilihan Atlet Panahan Menggunakan Metode Analitycal Hierarchy Process Berbasis Web yang menggambarkan aliran proses secara umum dengan admin sebagai user yang menginput data-data serta laporan. Tipe diagram yang akan digunakan dalam pengembangan sistem pendukung keputusan ini adalah use case diagram (user bertindak dengan sebuah sistem), activity diagram (perilaku prosedurtal dan paralel) dan sequence diagram (proses interaksi). Ketiga diagram ini menggambarkan secara umum proses input diberikan admin ke sistem.

Diagram use case adalah diagram yang menunjukan segala aktivitas dan proses menjalankan program aplikasi dari seseorang dengan system Berikut merupakan diagram use case pada Sistem Pendukung Keputusan Pemilihan Atlet Panahan Menggunakan Metode Analitycal Hierarchy Process Berbasis Web diagram use case dilihat pada Gambar 2.

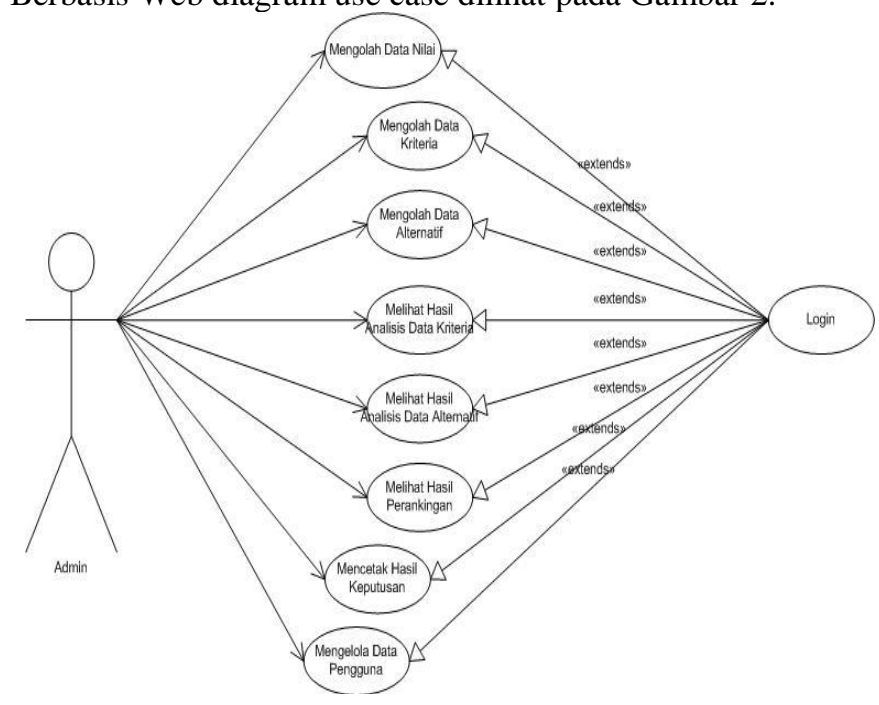

Gambar 2. Diagram Use Case
Dari gambar diatas dapat dijelaskan bahwa admin dapat melakukan login ke dalam sistem, melakukan pengolahan data nilai, melakukan pengolahan data kriteria, melakukan pengolahan data alternatif, melihat hasil analisa data kriteria, melihat hasil analisa data alternatif, melihat hasil perankingan dan mencetak hasil keputusan.

Apabila user / pemakai ingin menjalankan sistem informasi maka user diwajibkan untuk melakukan Login terlebih dahulu. Berikut adalah implementasi dari Form Login. Tampilan Form Login dapat dilihat pada Gambar 3.

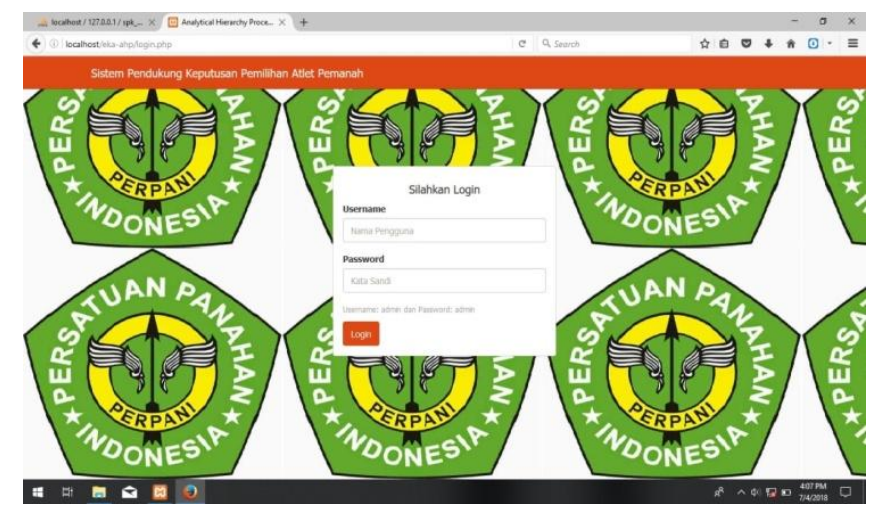

Gambar 3 Form Login

Setelah melakukan login, maka user akan dibawa pada form menu utama. Berikut adalah implementasi dari Form Menu Utama. Tampilan Form Menu Utama dapat dilihat pada Gambar 4.

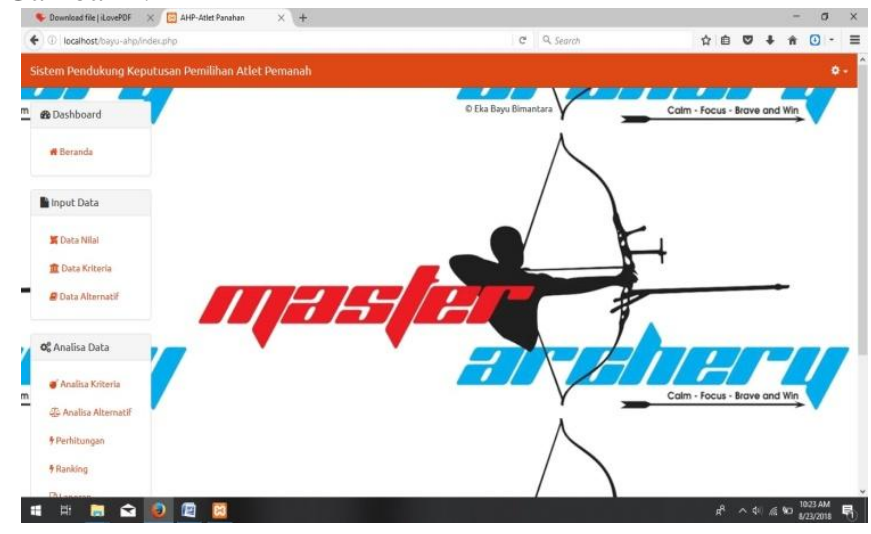

Gambar 4 Form Menu Utama

Apabila user ingin memasukan data nilai maka user akan masuk pada form input data nilai. Berikut adalah implementasi dari Form Nilai. Tampilan Form Input Data Nilai dapat dilihat pada Gambar 5. 


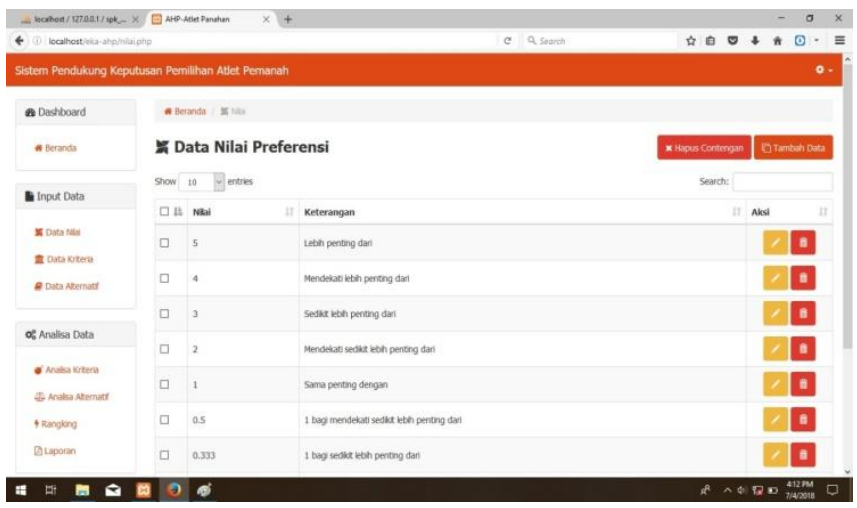

Gambar 5 Form Input Data Nilai

Apabila user ingin memasukan data kriteria maka user akan masuk pada form input data kriteria. Berikut adalah implementasi dari Form Kriteria. Tampilan Form Input Data Kriteria dapat dilihat pada Gambar 6.

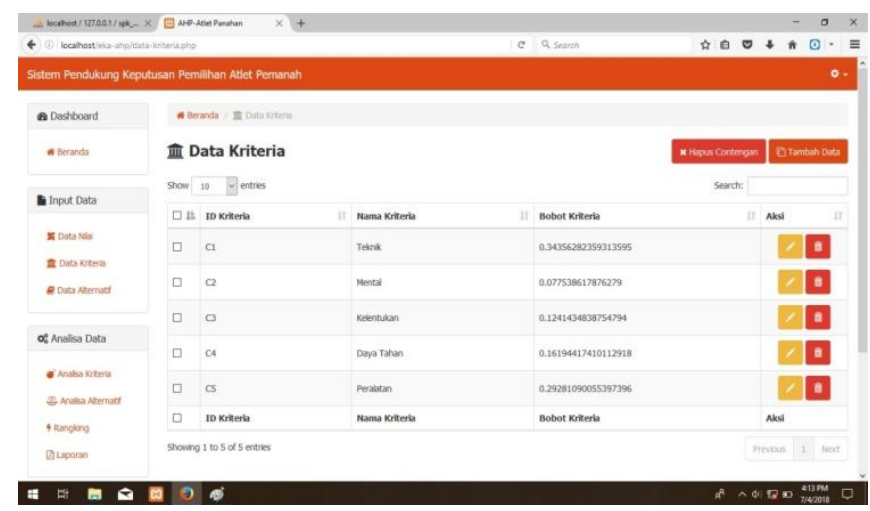

Gambar 6 Form Input Data Kriteria

Apabila user ingin memasukan data alternatif maka user akan masuk pada form input data alternatif. Berikut adalah implementasi dari Form Alternatif. Tampilan Form Input Data Alternatif dapat dilihat pada Gambar 7.

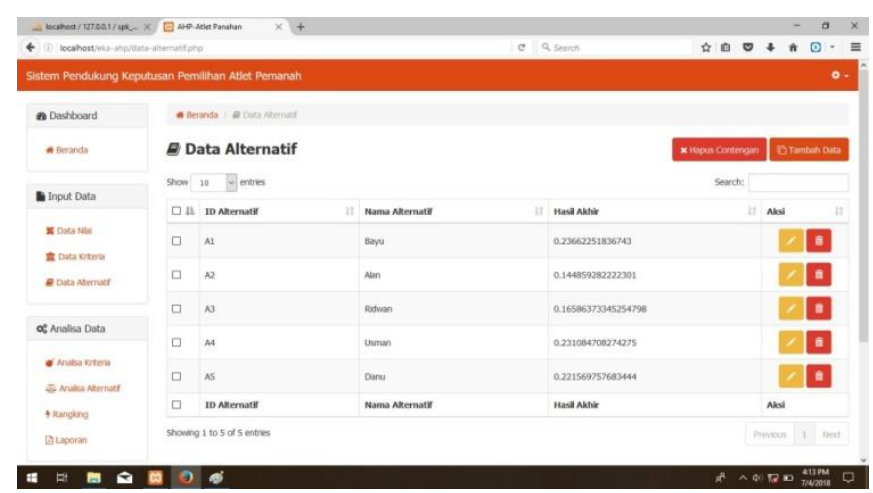

Gambar 7 Form Input Data Alternatif

Apabila user ingin memasukan data analisa kriteria maka user akan masuk pada form input data analisa kriteria. Berikut adalah implementasi dari Form Analisa Kriteria. Tampilan Form Input Data Analisa Kriteria dapat dilihat pada Gambar 8.

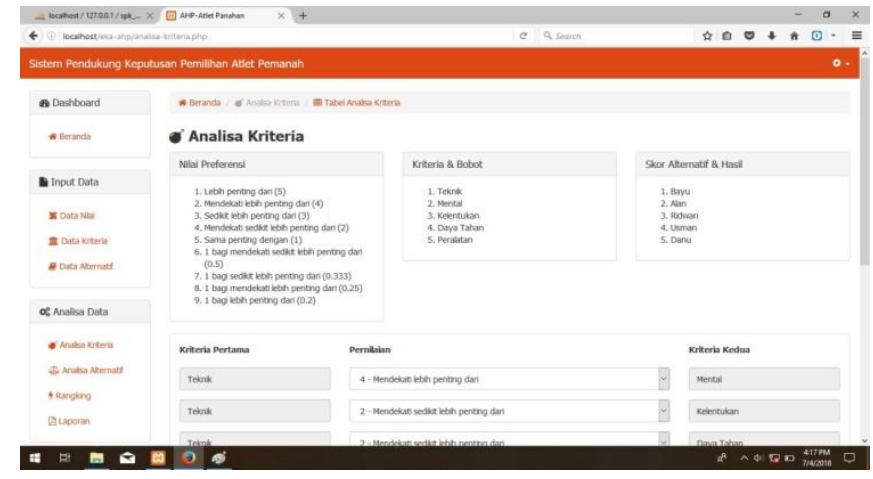

Gambar 8 Form Input Data Kriteria

Apabila user ingin memasukan data analisa alternatif maka user akan masuk pada form input data analisa alternatif. Berikut adalah implementasi dari Form Analisa Alternatif. Tampilan Form Input Data Analisa Alternatif dapat dilihat pada Gambar 9.

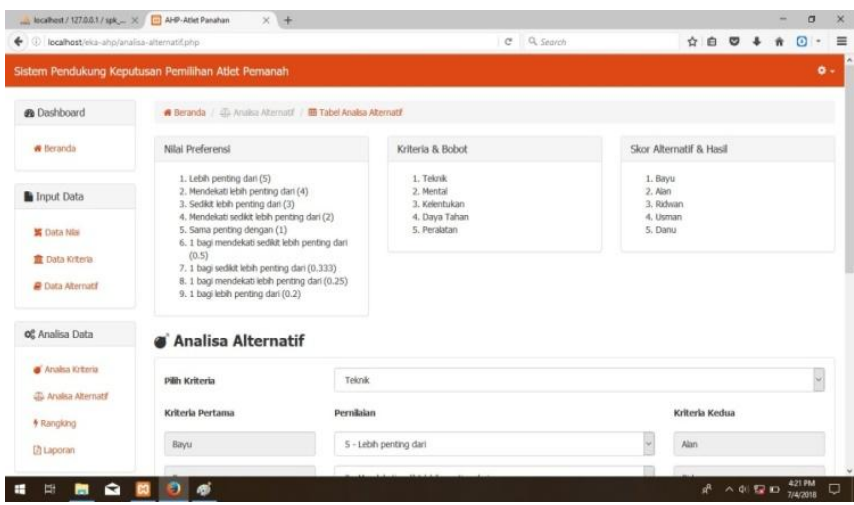

Gambar 9 Form Input Data Alternatif

Apabila user ingin melihat data analisa kriteria maka user akan masuk pada form input data analisa kriteria. Berikut adalah implementasi dari Form Analisa Kriteria. Tampilan Form Input Data Analisa Kriteria dapat dilihat pada Gambar 10 .

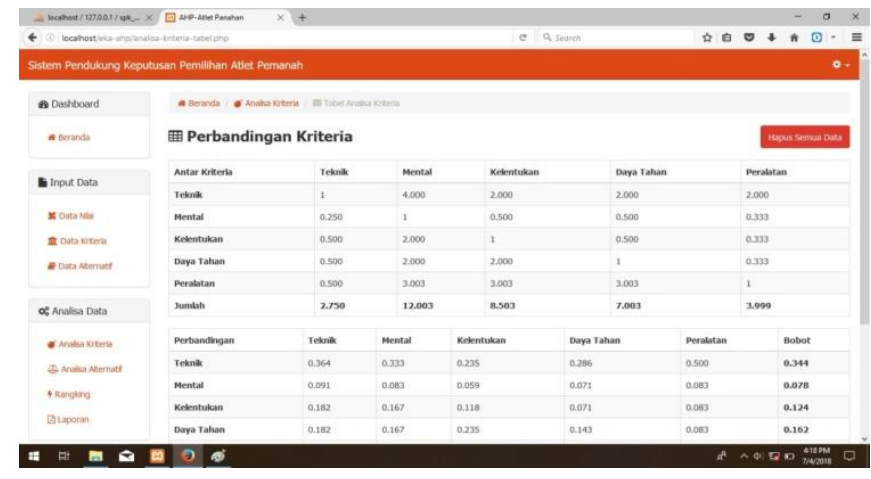

Gambar 10 Form Input Data Kriteria

Apabila user ingin melihat data analisa alternatif maka user akan masuk pada form input data analisa alternatif. Berikut adalah implementasi dari Form Analisa Alternatif. 
Tampilan Form Input Data Analisa Alternatif dapat dilihat pada Gambar 11.

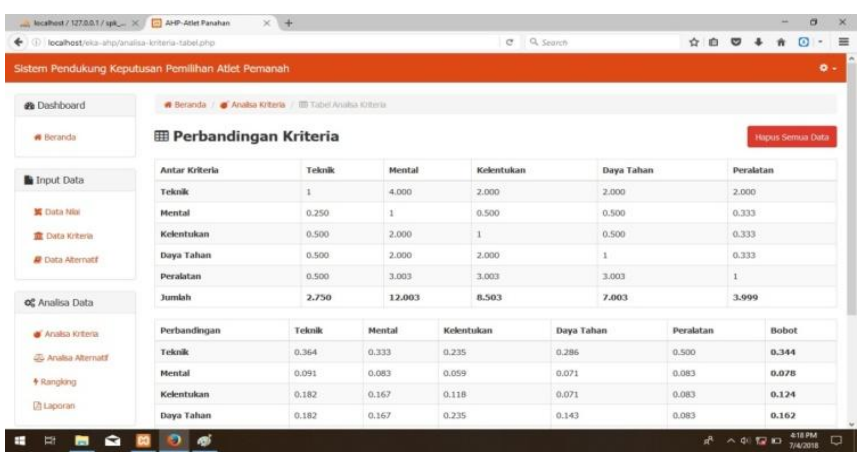

Gambar 11 Form Input Data Alternatif

Berikut adalah hasil analisa data criteria yang telah diperhitungkan oleh system, serta mendapat CR (Consistency Ratio)

$$
\begin{aligned}
\mathrm{CR} & =\frac{\mathrm{CI}}{\mathrm{IR}} \\
& =\frac{0.0075}{1.12} \\
& =0.006 \Rightarrow \mathrm{CR}<0.1 \Rightarrow \text { KONSISTEN }
\end{aligned}
$$

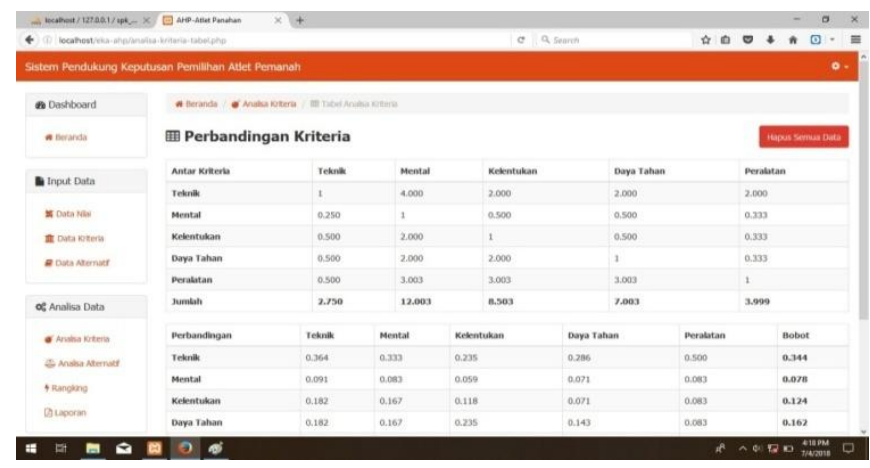

Gambar 12 Analisa Data Kriteria

Berikut adalah hasil analisa data criteria teknik yang telah diperhitungkan oleh system, serta mendapat CR (Consistency Ratio)

$$
\begin{aligned}
\mathrm{CR} & =\frac{\mathrm{CI}}{\mathrm{IR}} \\
& =\frac{0.0970}{1.12} \\
& =0.0086 \Rightarrow \mathrm{CR}<0.1 \Rightarrow \text { KONSISTEN }
\end{aligned}
$$

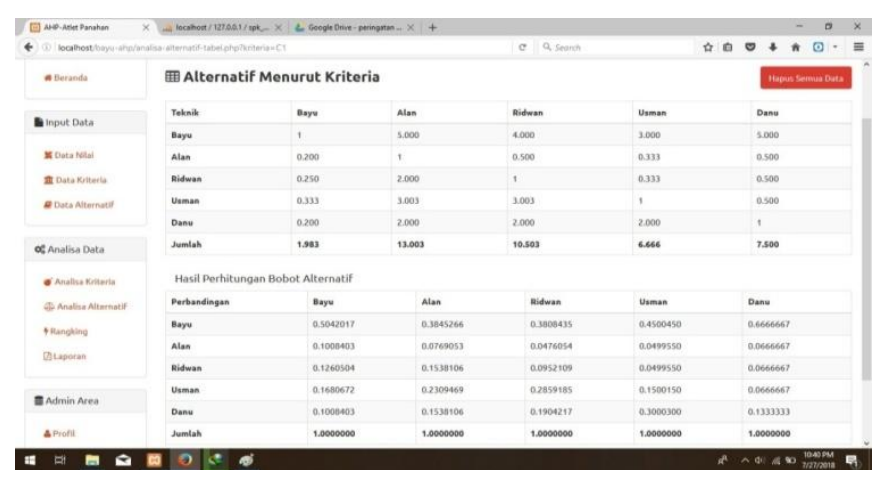

Gambar 13 Analisa Data Kriteria Teknik
Berikut adalah hasil analisa data criteria mental yang telah diperhitungkan oleh system, serta mendapat CR (Consistency Ratio)

$$
\begin{aligned}
\mathrm{CR} & =\frac{\mathrm{CI}}{\mathrm{IR}} \\
& =\frac{0.022}{1.12} \\
& =0.0201 \Rightarrow \mathrm{CR}<0.1 \Rightarrow \text { KONSISTEN }
\end{aligned}
$$

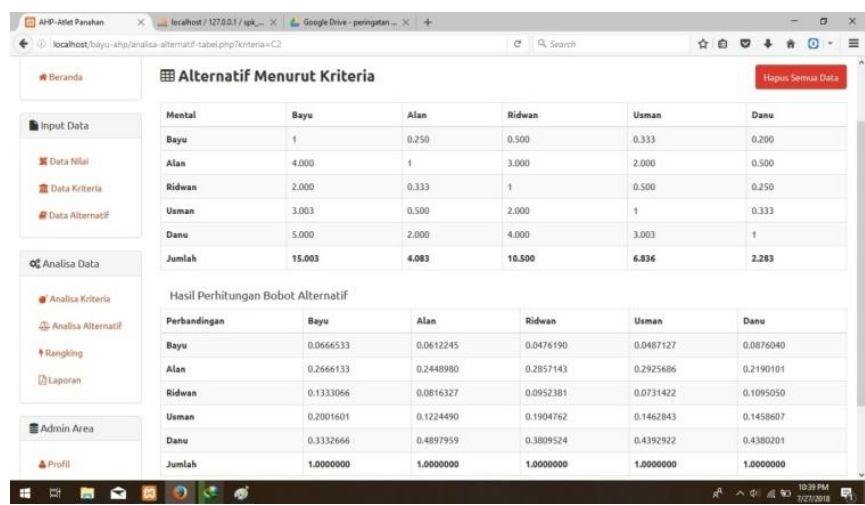

Gambar 14 Analisa Data Kriteria Mental

Berikut adalah hasil analisa data criteria kelentukan yang telah diperhitungkan oleh system, serta mendapat CR (Consistency Ratio)

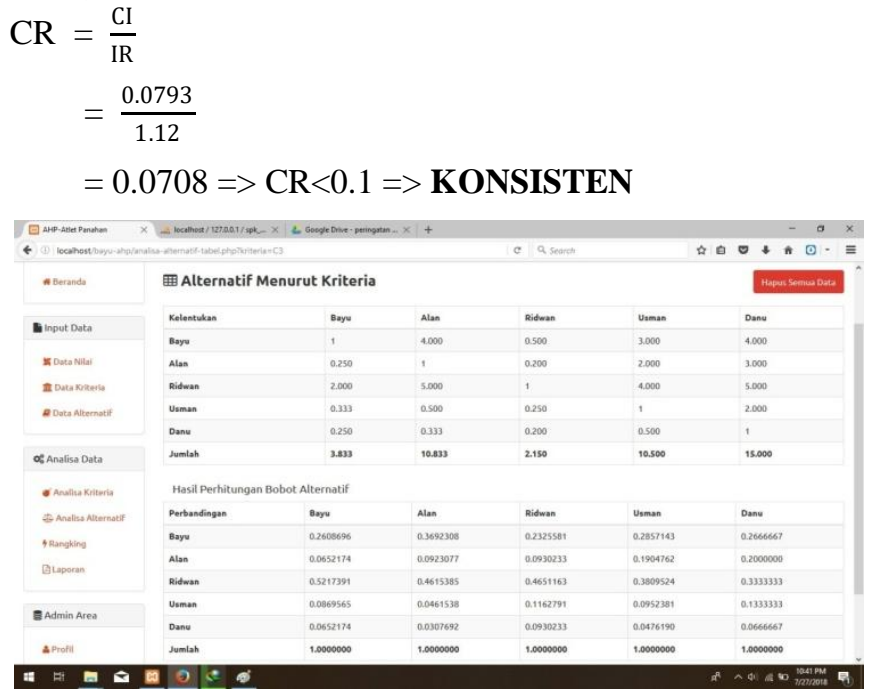

Gambar 15 Analisa Data Kriteria Kelentukan

Berikut adalah hasil analisa data criteria daya tahan yang telah diperhitungkan oleh system, serta mendapat CR (Consistency Ratio)

$$
\begin{aligned}
\mathrm{CR} & =\frac{\mathrm{CI}}{\mathrm{IR}} \\
& =\frac{0.0125}{1.12} \\
& =0.0028026 \Rightarrow \mathrm{CR}<0.1 \Rightarrow \text { KONSISTEN }
\end{aligned}
$$




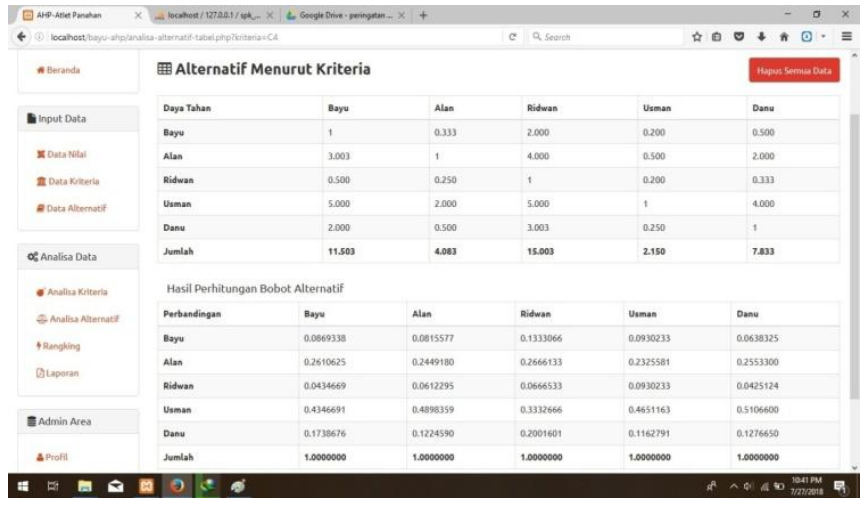

Gambar 16 Analisa Data Kriteria Daya Tahan

Berikut adalah hasil analisa data criteria peralatan yang telah diperhitungkan oleh system, serta mendapat CR (Consistency Ratio)

$$
\begin{aligned}
\mathrm{CR} & =\frac{\mathrm{CI}}{\mathrm{IR}} \\
& =\frac{0.036}{1.12} \\
& =0.032 \Rightarrow \mathrm{CR}<0.1 \Rightarrow \text { KONSISTEN }
\end{aligned}
$$

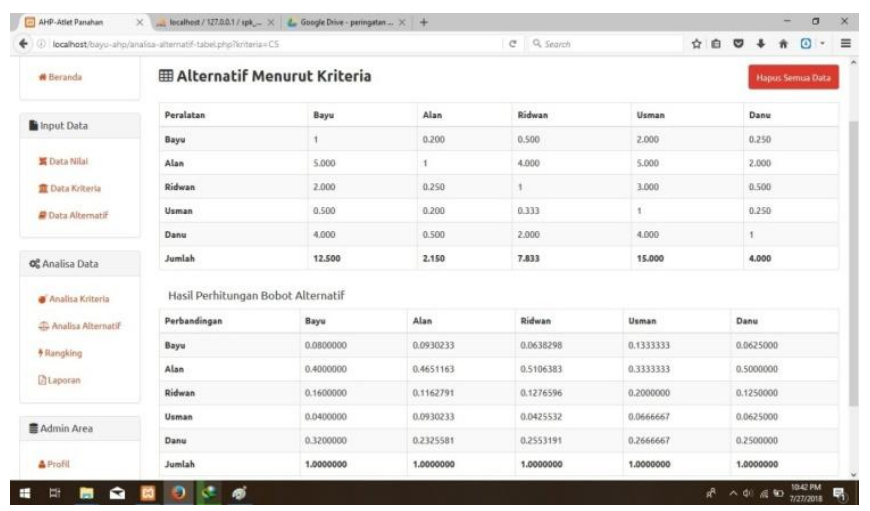

Gambar 17 Analisa Data Kriteria Peralatan

Apabila user ingin melihat hasil perankingan maka user akan masuk pada form ranking. Berikut adalah implementasi dari Form Catak Ranking. Tampilan Form Ranking dapat dilihat pada Gambar 18, 19 dan 20.

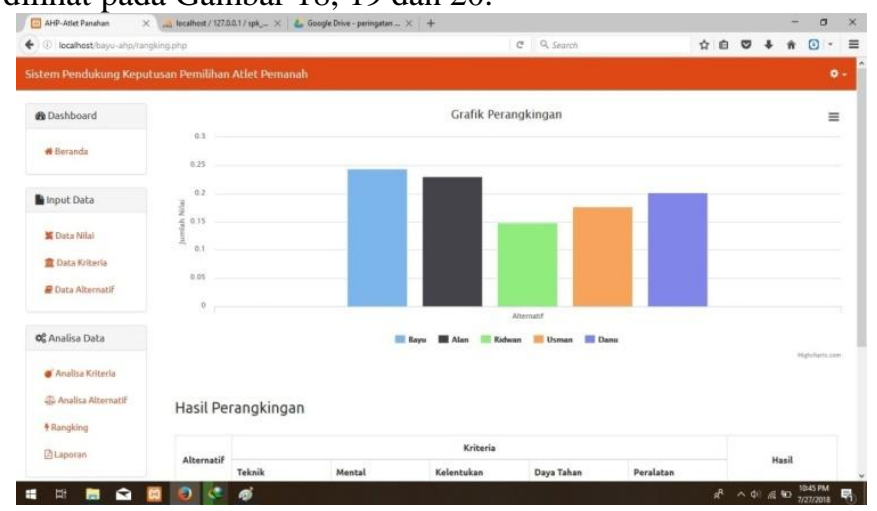

Gambar 18 Halaman Form Ranking

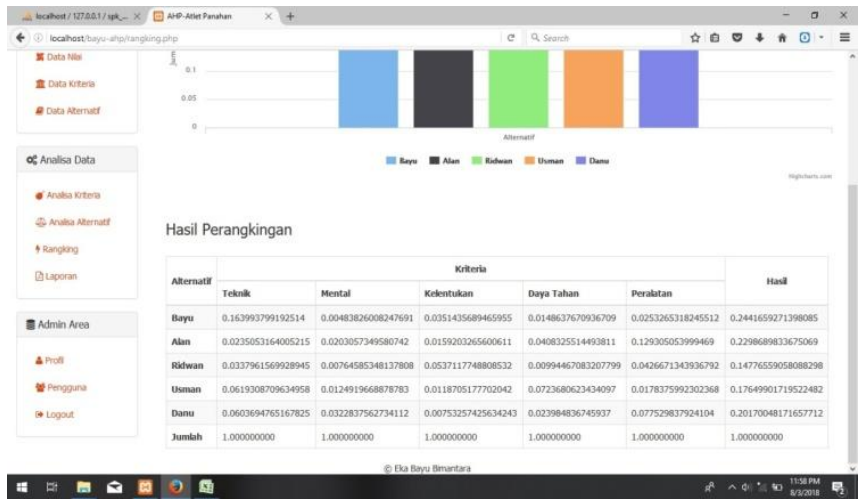

Gambar 19 Halaman Form Ranking

Untuk mendapatkan hasil perangkingan, didasarkan pada pohon bobot kriteria seperti pada Gambar 20. Dimana :

$\mathrm{A} 1=0,2441659271398$

$\mathrm{A} 2=0,2298689833675$

A3 $=0,1477655905809$

A4 $=0,1764990171952$

A5 $=0,2017004817166$

Alternatif 1 (A1) adalah Bayu, Alternatif 2 (A2) adalah Alan, Alternatif 3 (A3) adalah Ridwan, Alternatif 4 (A4) adalah Usman, dan Alternatif 5 (A5) adalah Danu.

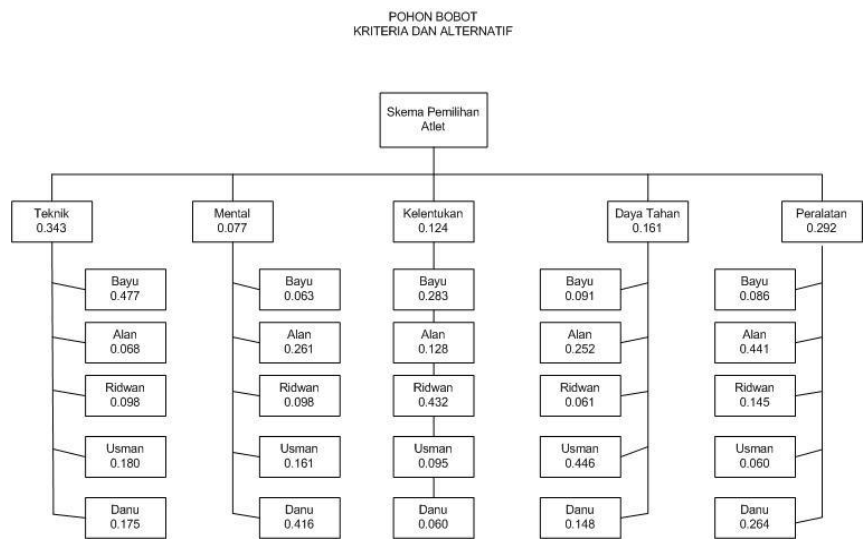

Gambar 20 Pohon Bobot Kriteria Dan Alternatif

Dari Gambar 20 didapatkan Urutan perangkingan seperti pada Gambar 21. Maka dapat dilakukan perankingan vector v dari hasil perbandingan setiap alternatif pada setiap kriteria .

$\mathrm{V} 1=\quad 0,2441659271398$ (Bayu)

$\mathrm{V} 2=\quad 0,2298689833675($ Alan $)$

$\mathrm{V} 3=\quad 0,2017004817166($ Danu $)$

$\mathrm{V} 4=\quad 0,1764990171952$ (Usman)

$\mathrm{V} 5=\quad 0,1477655905809($ Ridwan $)$ 


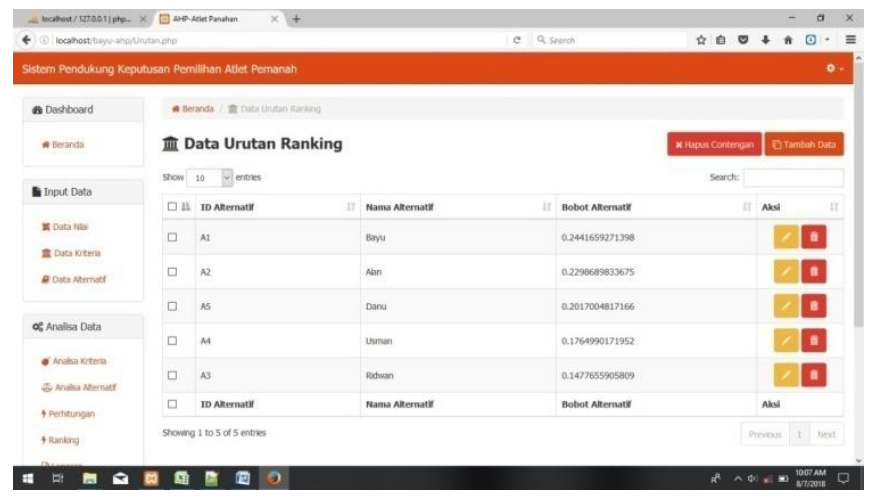

Gambar 21 Halaman Urutan Ranking

Setelah dilakukan implementasi, dilakukan pengujian sistem menggunakan Blackbox dan hasilnya dapat dilihat pada Tabel 1.

Tabel 1. Pengujian Menggunakan BlackBox.

\begin{tabular}{|c|c|c|c|}
\hline No & Skenario Pengujian & Tes & Hasil \\
\hline 1 & $\begin{array}{l}\text { Menginputkan data } \\
\text { username dan password } \\
\text { dengan benar, lalu klik } \\
\text { tombol Login }\end{array}$ & $\begin{array}{l}\text { Username:admin } \\
\text { Password } \\
\text { :admin }\end{array}$ & Sesuai Harapan \\
\hline 2 & $\begin{array}{l}\text { Menginputkan form data } \\
\text { nilai preferansi, tambah } \\
\text { data nilai preferensi, edit } \\
\text { serta hapus data nilai } \\
\text { preferensi sesuai dengan } \\
\text { keinginan }\end{array}$ & $\begin{array}{l}\text { Tambah, edit, } \\
\text { hapus data nilai } \\
\text { preferensi }\end{array}$ & Sesuai Harapan \\
\hline 3 & $\begin{array}{l}\text { Menginputkan form data } \\
\text { kriteria, tambah data } \\
\text { kriteria, edit serta hapus } \\
\text { data kriteria sesuai dengan } \\
\text { keinginan }\end{array}$ & $\begin{array}{l}\text { Tambah, edit, } \\
\text { hapus data } \\
\text { nkriteria }\end{array}$ & Sesuai Harapan \\
\hline 4 & $\begin{array}{l}\text { Menginputkan form data } \\
\text { alternatif, tambah data } \\
\text { alternatif, edit serta hapus } \\
\text { data alternatif sesuai } \\
\text { dengan keinginan }\end{array}$ & $\begin{array}{l}\text { Tambah, edit, } \\
\text { hapus data } \\
\text { alternatif }\end{array}$ & Sesuai Harapan \\
\hline 5 & $\begin{array}{l}\text { Menginputkan form data } \\
\text { himpunan kriteria edit data, } \\
\text { serta hapus data sesuai } \\
\text { dengan keinginan }\end{array}$ & $\begin{array}{l}\text { Tambah, edit, } \\
\text { hapus data } \\
\text { himpunan } \\
\text { kriteria }\end{array}$ & Sesuai Harapan \\
\hline 6 & $\begin{array}{l}\text { Melihat halaman analisa } \\
\text { criteria }\end{array}$ & $\begin{array}{l}\text { Perhitungan } \\
\text { nilai preferensi } \\
\text { dan bobot } \\
\text { kriteria }\end{array}$ & Sesuai Harapan \\
\hline 7 & $\begin{array}{l}\text { Melihat halaman analisa } \\
\text { alternatif }\end{array}$ & $\begin{array}{l}\text { Perhitungan } \\
\text { nilai preferensi } \\
\text { dan bobot } \\
\text { alternatif }\end{array}$ & Sesuai Harapan \\
\hline 8 & Melihat hasil perankingan & $\begin{array}{l}\text { Perhitungan } \\
\text { antara data nilai } \\
\text { preferensi data } \\
\text { criteria dan data } \\
\text { alternatif }\end{array}$ & Sesuai Harapan \\
\hline 9 & $\begin{array}{l}\text { Melihat Form Laporan, } \\
\text { Cetak }\end{array}$ & Klik Cetak & Sesuai Harapan \\
\hline
\end{tabular}

Pada pengujian sistem didapatkan akurasi tingkat keberhasilan menggunakan beberapa butir uji antara lain, Login, Halaman Utama, Halaman Data Nilai, Halaman Data Kriteria, Halaman Analisa Kriteria, Halaman Analisa Alternatif, Halaman Tabel Analisa Kriteria, Halaman Tabel Analisa Alternatif, Halaman Perankingan, Halaman Pengguna dan Logout. Berdasarkan hasil Black Box tersebut, didapatkan hasil yang sesuai harapan pada butir uji. Sehingga dapat disimpulkan prosentase akurat keberhasilan sistem sebesar $100 \%$.

\section{KESIMPULAN}

Pada hasil pengujian yang telah dilakukan pada sistem pendukung keputusan pemilihan atlet panahan menggunakan metode Analitycal Hierarchy Process, maka dapat diambil kesimpulan bahwa pengembangan aplikasi ini berhasil dengan tingkat keberhasilan 100\% pada Black Box, dan website yang di kembangkan ini dapat digunakan untuk membantu para pelatih PERPANI dalam melakukan pengambilan keputusan pemilihan atlet panahan yang mempunyai kemampuan mumpuni.

\section{DAFTAR PUSTAKA}

Armiyana., C. M. Reski. 2017. Sistem Pendukung Keputusan Pemilihan Se Sekolah Anak Dengan Metode Analitycal Hierarchy Process (AHP) dan Metode Perbandingan Eksponsional (MPE). Jurna; CoreIT. Vol.3. No.1

Bangkit, Rizky., Regasari, Rekyan., Mahmudy, W. F. 2014 Sistem Pendukung Keputusan Pemilihan Atlet Yang Layak Masuk Tim Pencak Silat dengan Metode Simple Additive Weighting (SAW). Jurnal Mahasiswa PTNK. Vol.4. No.4. Universias Brawijaya.

Fahrozi, Wirhan. 2016. Penerapan Metode Analitycal Hierarchy Process (AHP) dalam Menentukan Ras Ayam Serama. Creative Information Technology Journal 3.

Nugroho, A. S. 2016. Sistem Pendukung Keputusan Seleksi Atlet PON Hockey Kontingen Jawa Tengah Menggunakan Metode AHP dan Promethee.Universitas Negeri Semarang. Skripsi.

Rimantho, Dino dkk. 2016. Aplikasi AHP Pada Pemilihan Metode Analisis Zat Organik Dalam Air. JITI, Vol.15 (1)

Setiawan. R. 2011. Sistem Pendukung Keputusan Untuk Menentukan Kelayakan Polisi Dalam Memegang Senjata Api Menggunakan Scoring Sistem. Malang.

Setyawan, Aji., Sutariyani. 2013. Sistem Pendukung Keputusan Seleksi Calon Atlit Bulutangkis Berbakat PB. Djarum Kudus. Jurnal Ilmiah Go Infotech. Vol. 19. No.1. ISSN:1693-590x. 